\title{
Constitutive Production of Macrophage Colony-stimulating Factor by Human Ovarian and Breast Cancer Cell Lines
}

\author{
S. Ramakrishnan," F. J. Xu," S. J. Brandt, " J. E. Niedel,“ R. C. Bast, Jr.," and E. L. Brown \\ *Department of Medicine, Duke University Medical Center, Durham, North Carolina 27710; and ${ }^{\ddagger}$ Genetics Institute Inc., \\ Cambridge, Massachusetts 02140
}

\begin{abstract}
Many nonhematologic tumors produce growth factors that may influence cellular proliferation either by autocrine or by paracrine mechanisms. In the current study, human tumor cell lines were investigated for the constitutive production of macrophage colony-stimulating factor (M-CSF). Culture supernatants obtained from cell lines were analyzed using a radioimmunoassay and a radioreceptor assay specific for M-CSF. Among the various cell types analyzed, all the ovarian cell lines and a majority of the breast cancer cell lines secreted significant amount of an M-CSF-like factor. Treatment of mouse bone marrow cultures with culture supernatants from ovarian cancer cells stimulated the production of macrophage colonies. Analysis of total cellular RNA obtained from the ovarian cell lines by Northern blot showed multiple sizes of M-CSF transcripts with an abundance of a 4.2-kb message. The relative amount of M-CSF transcripts correlated with the level of immunoreactive material seen in the culture supernatants.
\end{abstract}

\section{Introduction}

Significant progress has been made recently in identifying various internal and external signals that affect the growth of tumor cells. Production of growth factors by some tumors suggest that autocrine or paracrine mechanisms might regulate the tumor growth. In several tumor systems, the cellular homologues of retroviral oncogenes are activated that encode for either growth factors (e.g., B-chain of platelet derived growth factor, coded by the proto-oncogene, c-sis; 1, 2) or growth factor receptors (c-fms, c-erb-B-2; 3-5). The induction or over-expression of growth factor related genes in cancer cells may be caused by translocation, gene rearrangement, or transactivation (6-10). These changes could in turn affect the homeostasis of cellular proliferation.

Ovarian carcinoma is responsible for more deaths annually than any other gynecological neoplasm. Frequently, the growth of ovarian tumors is associated with increased infiltration of $T$ cells and macrophages. The increased number of macrophages seen at the tumor site in many cases is not due to secondary infection. Further, animals bearing tumor trans-

Address reprint requests to Dr. Ramakrishnan, Box 3843, Department of Medicine, Duke University Medical Center, Durham, NC 27710. Dr. Brandt's current address is Clinical Hematology Branch, National Institutes of Health, Bethesda, MD 20892.

Received for publication 17 June 1988 and in revised form 12 September 1988 .

J. Clin. Invest.

(C) The American Society for Clinical Investigation, Inc.

0021-9738/89/03/0921/06 \$2.00

Volume 83, March 1989, 921-926 plants have elevated numbers of granulocytes and monocytes in peripheral blood $(11,12)$. Similarly, elevated granulocyte counts are frequently observed in patients with tumors (13, 14). Polypeptide growth factors produced by tumor cells might contribute to the increased granulopoiesis. In fact, colony stimulating factors can be isolated from tumor extracts (15, 16). Activation of inflammatory cells may inhibit tumor growth, but macrophages or their products might also stimulate the tumor cell growth. The growth of primary ovarian tumor cells and established cell lines in vitro are greatly influenced by the addition of macrophage-conditioned medium. The presence of phagocytic and adherent cells increased the ability of human tumor cells to form colonies in semisolid medium (17). Conversely, the depletion of macrophages from ovarian carcinoma effusions has lead to decreased cloning efficiency (17). The increase in clonogenic growth of tumor cells is not dependent on the source of macrophages since even xenogenic peritoneal macrophages were able to improve the cloning efficiency of primary ovarian tumor cells in culture (18).

In a recent report, Mills et al. (19), have identified putative growth factors with mitogenic properties in the ascites fluid obtained from ovarian cancer patients. Effusions from other type of tumors did not stimulate ovarian cancer cells. In the present study, experiments were carried out to identify the production of a colony stimulating growth factor involved in the interaction between ovarian tumor cells and macrophages.

\section{Methods}

Cell lines. Human tumor cell lines belonging to four different groups were maintained in tissue culture.

Leukemia cells. T lymphoblastic cell lines (HSB-2, CEM, MOLT-4), Burkitt's lymphoma cells (Raji, Ramos, and ConcF) and myelogenous leukemia cells (KG-1 and KGla) were obtained from American Tissue Culture Collection, Rockville, MD (ATCC). KG-1 and KG-1a cells were grown in IMDM containing $20 \%$ fetal bovine serum (FBS; Hazelton, Lenexa, KS), 2 mM L-glutamine, $100 \mathrm{IU} / \mathrm{ml}$ penicillin, and $50 \mu \mathrm{g} / \mathrm{ml}$ streptomycin. Other cells were cultured in RPMI 1640 medium supplemented with 15\% FBS and antibiotics. HL-60, a human promyelocytic leukemia cell line, was grown in RPMI 1640 medium containing $20 \%$ FBS. In addition, a murine myeloblastic leukemia cell line, M-1 (ATCC) was also used in this study.

Breast cancer cell lines. SK-BR-3 (20), CAMA-1 (21), BT-483 (22), and MCF7 (23) were obtained from Cetus Corp. (Emeryville, CA). BT-20 breast cancer cell line was obtained from Dr. Arthur Bogden (24). Cells were grown in RPMI 1640 medium (SK-BR-3, BT-483, and BT-20) with 10-15\% FBS, 2 mM L-glutamine and antibiotics. CAMA 1 and MCF7 cells were cultured in Dulbecco's modified minimal essential medium containing $15 \%$ and $6 \%$ FBS, respectively. In addition, porcine insulin (Sigma Chemical Co., St. Louis, MO) was added to BT-20 and MCF7 cultures.

Ovarian carcinoma cell lines. Six ovarian cancer cells were used in this study; OVCAR-3, OVCA-420, OVCA-429, OVCA-432, 
OVCA-433, and DOV-13. OVCAR-3 cells were obtained from ATCC; OVCA-420, OVCA-429, OVCA-432, and OVCA-433 were established from ascites obtained from ovarian carcinoma patients in collaboration with Dr. Herbert Lazarus (25). DOV-13 was derived in our laboratory (unpublished work). All ovarian cells were cultured in DMEM containing $10 \%$ FBS, 2 mM L-glutamine and antibiotics. In addition, 1 $\mathrm{mM}$ sodium pyruvate and $1 \%$ nonessential amino acid mixture were added. Routinely, the cells were subcultured once a week.

Human bladder carcinoma cell lines. Transitional cell carcinoma cell lines (5637, RT-4) were obtained from ATCC and maintained in RPMI 1640 medium containing 10\% FBS, 2 mM L-glutamine, and antibiotics.

Other cell line. A normal human foreskin fibroblast cell line, Huff, was obtained from Dr. Kay Singer (Duke University Medical Center) and cultured in DMEM containing 10\% FCS, 2 mM L-glutamine and antibiotics.

The culture supernatants were passed through a $0.45-\mu \mathrm{m}$ filter and concentrated (30- to 50 -fold) by ultrafiltration (Amicon Corp., Danvers, MA) using YM-10 filter disks and analyzed for the presence of macrophage colony-stimulating factors (M-CSF). ${ }^{1}$

Radioiodination of human recombinant $M-C S F$. Highly purified human recombinant $M-C S F$ was provided by Genetics Institute, Cambridge, MA. The growth factor was labeled with $\mathrm{Na}^{125} \mathrm{I}$ using iodogen (Pierce Chemicals, Rockford, IL). Iodogen was dissolved in chloroform and $10 \mu \mathrm{g}$ of the reagent was added to borosilicate tubes (12 $\times 75 \mathrm{~mm}$ ) and evaporated to dryness under nitrogen. $50 \mu \mathrm{l}$ of phosphate buffer, $0.5 \mathrm{M}, \mathrm{pH} 7.4$ was added to iodogen-coated tube. M-CSF, $10 \mu \mathrm{g}$ was taken in a volume of $10 \mu \mathrm{l}$. Iodination was carried out by the addition of $\mathrm{Na}^{125} \mathrm{I}(0.25 \mathrm{mCi}$; Amersham Corp., Arlington Heights, IL) and incubated on ice for $30 \mathrm{~min}$. The labeled protein was separated from free iodine by gel filtration on a PD-10 (Pharmacia Fine Chemicals, Piscataway, NJ) column. The specific activity of the radioiodinated M-CSF ranged from 17.2 to $46.0 \mu \mathrm{Ci} / \mu \mathrm{g}$ protein in six different experiments.

Determination of human $M-C S F$ by radioimmunoassay. Polyclonal antiserum against human recombinant M-CSF was generated in rabbits by hyperimmunization. The antiserum used in this study was highly specific and did not crossreact with other growth factors/lymphokines like recombinant GM-CSF, recombinant IL-2 and gamma interferon (data not included). The competitive inhibition assay consisted of $50 \mu \mathrm{l}$ of appropriately diluted antiserum (1:30,000), $50 \mu \mathrm{l}$ of labeled M-CSF $(\sim 10,000 \mathrm{cpm})$ and $50 \mu \mathrm{l}$ of culture supernatants or standard recombinant $\mathrm{M}$-CSF. The tubes were incubated at $4^{\circ} \mathrm{C}$ for 18 $\mathrm{h}$ to attain equilibrium. Antibody bound radiolabeled M-CSF was differentially precipitated from free label by $15.0 \%$ polyethyleneglycol (PEG 6000) prepared in PBS, pH 7.4. To facilitate quantitative recovery, $100 \mu$ l of 1:10 diluted normal rabbit serum was added to each tube as a carrier. After an additional period of incubation for $4 \mathrm{~h}$ in cold, the tubes were centrifuged for $30 \mathrm{~min}$ at $2,000 \mathrm{rpm}$ in a refrigerated centrifuge $\left(4^{\circ} \mathrm{C}\right)$. The radioactivity associated with the pellet was determined in an Auto-Gamma counter 5780 (Packard Instrument Co., Inc., Downers Grove, IL). The data was analyzed by Logit transformation and the amount of M-CSF present in culture supernatant was estimated from the dose-response curve obtained with standard recombinant M-CSF.

Radioreceptor assay. Mouse myeloid leukemia cells M1, express low but significant amount of receptors for M-CSF (26). M1 cells (2 $\left.\times 10^{6}\right)$ in a volume of $100 \mu \mathrm{l}$ were incubated with radioiodinated M-CSF $(\sim 25 \mathrm{pM})$ in the presence or absence of competing reagents $(50 \mu$ l). The total volume of the reaction mixture was $200 \mu l$. After incubation at $4^{\circ} \mathrm{C}$ overnight, the cells were washed with saline and harvested using a cell harvester (Skatron Inc., Sterling, VA). Under these conditions, $\sim 2.0 \%$ of the total radioactivity was specifically bound to the cells. To reduce nonspecific binding of radioiodinated

1. Abbreviations used in this paper: CFU-M, macrophage colonyforming unit; M-CSF, human macrophage colony-stimulating factor.
M-CSF, 96-well plates and filter papers used for harvesting were pretreated with PBS containing 3.0\% BSA for $1 \mathrm{~h}$ at room temperature.

Bone marrow culture. 8-wk-old female Balb/c mice were killed and the femurs were removed under aseptic conditions. Marrow was flushed through the cut ends by injecting tissue culture medium using a $27 \mathrm{G}$ needle. Single cell suspension was prepared by repeated aspiration.

One million nucleated cells were resuspended in $0.3 \%$ agarose prepared in IMDM containing 30\% FCS and 5\% lymphocyte-conditioned medium. The latter was obtained by culturing human peripheral blood lymphocytes with $5 \mu \mathrm{g} / \mathrm{ml}$ of phytohemagglutinin for $96 \mathrm{~h}$. The conditioned medium was passed through a $0.2-\mu \mathrm{m}$ filter and stored at $-70^{\circ} \mathrm{C}$. The test culture supernatants (obtained from ovarian cancer cell lines, BT-20, a breast cancer cell line, and M1 cells) were included in the $0.3 \%$ agarose medium before the addition of bone marrow cells. As a positive control, bone marrow cells were treated with known amount of recombinant M-CSF. The cell suspension in $0.3 \%$ agarose was layered over $0.6 \%$ agarose in $35-\mathrm{mm}$ petri dishes with grids. Bone marrow cultures were incubated for $1 \mathrm{wk}$ before scoring the number of macrophage colony forming units (CFU-M) under an inverted phasecontrast microscope. The colonies were identified by nonspecific esterase staining according to the method of Kubota et al. (27).

Extraction of RNA and Northern blot analysis. Total cellular RNA was isolated by the guanidine isothiocyanate method (28) from the indicated tumor cell lines and from HL-60 cells cultured for $48 \mathrm{~h}$ with $32 \mathrm{nM}$ phorbol myristate acetate (29). Denatured RNA $(20 \mu \mathrm{g})$ was fractionated in $1.2 \%$ agarose gels containing $7 \%$ formaldehyde and transferred to nitrocellulose filters by capillary action in $10 \times \operatorname{SSC}(1 \times$ $\mathrm{SSC}=0.15 \mathrm{M}$ sodium chloride, $0.015 \mathrm{M}$ sodium citrate; 30 ). Before transfer, the gels were soaked for $5 \mathrm{~min}$ in a dilute solution of acridine orange (Sigma Chemical Co.) and washed with distilled water. This method facilitates the localization of ribosomal RNAs by quenching under ultraviolet light and also help in the visualization after transfer. The intensity of ribosomal RNA bands were comparable in each lane indicating uniform transfer efficiency. The filters were baked under vacuum at $85^{\circ} \mathrm{C}$ and prehybridized overnight at $42^{\circ} \mathrm{C}$ in a buffer containing $50 \%$ formamide, $1 \times$ Denhardt's solution, $5 \times$ SSC, $50 \mathrm{mM}$ sodium phosphate (pH 6.5 ), $0.5 \% \mathrm{SDS}$, and $0.15 \mathrm{mg} / \mathrm{ml}$ of denatured salmon sperm DNA. An oligonucleotide corresponding to bases 344-391 of a published M-CSF cDNA sequence (31) was synthesized on an Applied Biosystem DNA synthesizer, gel-purified and labeled with $\left[{ }^{32} \mathrm{P}\right] \mathrm{AATP}$ (3,000 Ci/mM; New England Nuclear, Boston, MA) using terminal deoxynucleotidyl transferase to a specific activity greater than $6 \times 10^{7} \mathrm{cpm} / \mathrm{pM}$. The labeled probe was added to fresh buffer $\left(1 \times 10^{6} \mathrm{cpm} / \mathrm{ml}\right)$ and hybridization was carried out at $42^{\circ} \mathrm{C}$ for $24 \mathrm{~h}$. Filters were then washed for $1 \mathrm{~h}$ with four changes of $1 \times$ SSC containing $0.1 \%$ SDS at $55^{\circ} \mathrm{C}$, dried and exposed to $\mathrm{x}$-ray film (Kodak $\mathrm{X}$-Omat $\mathrm{AR}$ ) at $-70^{\circ} \mathrm{C}$ with a single intensifying screen. RNA standards (RNA ladder; Bethesda Research Laboratories, Gaithersburg, $\mathrm{MD}$ ) were run in parallel and visualized by autoradiography after hybridization with nick-translated lambda DNA. Nick-translation was carried out according to manufacturer's (BRL) specifications.

\section{Results}

Production of M-CSF by human tumor cell lines. Culture supernatants collected from the four groups of cell lines were analyzed for the presence of M-CSF using a radioimmunoassay. None of the T-lymphoblastic leukemia cells and Burkitt's lymphoma cells produced any detectable M-CSF. The myeloid leukemia cells, KG-1 and KG-1a were positive, but produced only a small amount of the growth factor. Interestingly, the synthesis of M-CSF was prevalent among the epithelial tumor cell lines. In the present study, two types of epithelial cancer cell lines were investigated. All six ovarian carcinoma cell lines secreted significant amounts of M-CSF into the culture me- 
Table I. Quantitation of M-CSF in the Culture Supernatants of Tumor Cell Lines

\begin{tabular}{llr}
\hline \multicolumn{1}{c}{ Cell type } & \multicolumn{1}{c}{ Name } & M-CSF \\
\hline \multirow{4}{*}{ T-lymphoblastic leukemia } & & $p M$ \\
& HSB-2 & *ND (2) \\
& CEM & ND (2) \\
Burkitt's lymphoma & MOLT-4 & ND (2) \\
& Raji & ND (2) \\
Myeloid leukemia & Ramos & ND (2) \\
& ConcF & ND (2) \\
Ovarian carcinoma & KG-1 & $1.8(3)$ \\
& KG-1a & $1.7(3)$ \\
& OVCA-420 & $7.6(3)$ \\
& OVCA-429 & $6.3(2)$ \\
& OVCA-432 & $5.2(2)$ \\
Bladder cancer & DOV-13 & $5.2(2)$ \\
& OVCA-433 & $2.8(2)$ \\
Breast cancer & OVCAR-3 & $0.7(3)$ \\
& 5637 & ND (2) \\
& RT-4 & ND (2) \\
& CAMA-1 & $5.3(3)$ \\
Fibroblast & BT-483 & $1.8(3)$ \\
Mouse myeloblast & SK-BR-3 & $1.6(3)$ \\
& BT-20 & ND (2) \\
& MCF7 & ND (2) \\
& Huff & $8.8(2)$ \\
& M1 & ND (2) \\
& &
\end{tabular}

* M-CSF was determined in a specific radioimmunoassay system. ND represents values below the detection limit of the assay system $(<0.5 \mathrm{pM})$. Culture supernatants from adherent cells (ovarian, breast, bladder carcinoma cells, and fibroblast) were collected at confluency (day 7). Media from lymphoid cell lines were collected on day 4 after subculture. Values in parentheses indicate the number of independent experiments.

dium. There were, however, variations in the amounts of growth factor produced. OVCAR-3 cells secreted small amounts of M-CSF, whereas OVCA-420, OVCA-432, OVCA-429 and DOV-13 cell lines showed a higher concentration of M-CSF in the culture supernatants (Table I). The other ovarian cancer cell line, OVCA-433, showed an intermediate level of M-CSF.

Among the breast cancer cell lines, CAMA-1 secreted high levels of the growth factor, while SK-BR-3 and BT-483 cells produced significant, but lower amounts of M-CSF in the medium. BT-20 and MCF7 cultures were negative for the production of M-CSF. The two bladder carcinoma cell lines tested did not secrete any significant amount of M-CSF. A human fibroblast cell line, Huff, produced the highest level of colony stimulating factor.

To determine the relative amount of growth factor produced by the ovarian cells, $10^{6}$ cells were grown for $48 \mathrm{~h}$ in culture, the culture supernatant was collected and analyzed for the presence of M-CSF. The data in Table II show the quantitative differences in the production of M-CSF by ovarian cells. As in the case of confluent cultures, OVCA-432 and OVCA-420 cells produced higher levels of M-CSF, while OVCA-433 cells showed a lower amounts of M-CSF.
Table II. Relative Amounts of M-CSF Produced by Ovarian Cancer Cells Over a Period of 48 Hours

\begin{tabular}{cc}
\hline Cell line & *M-CSF \\
\hline & $p M$ \\
OVCA-420 & 0.29 \\
OVCA-432 & 0.31 \\
OVCA-433 & 0.11 \\
OVCAR-3 & 0.04
\end{tabular}

1 million ovarian carcinoma cells were cultured for $48 \mathrm{~h}$ and the culture supernatants were analyzed for M-CSF by radioimmunoassay. Each value is a mean of duplicate cultures.

* Values represent the production of M-CSF by $5 \times 10^{4} \mathrm{cells} / \mathrm{ml}$ (seeding density) over a period of $48 \mathrm{~h}$.

The culture supernatants from ovarian cancer cells were further analyzed in a radioreceptor assay using a murine myeloid cell line, M1 (Fig. 1). In this assay system, the competitive inhibition is linear between 5 and $200 \mathrm{ng} / \mathrm{ml}$ when plotted after logit transformation. Inclusion of culture media from ovarian cancer cells inhibited competetively the binding of radioiodinated M-CSF to M1 cells. The profile of inhibition was similar to the results obtained in RIA. Culture supernatants having higher level of immunoreactive M-CSF like material also showed higher level of inhibition in the radioreceptor assay.

Effect of tumor cell culture supernatants on bone marrow cells. To assess the functional activity of M-CSF like factors secreted by the human tumor cell lines in vitro, bone marrow cultures were used. Data in Table III show the number of macrophage colonies (CFU-M) produced in the presence of ovarian cell culture supernatants. The control untreated bone marrow cultures showed an average of 1.5 CFU-M colonies per 1 million nucleated cells. Addition of human recombinant $\mathrm{M}-\mathrm{CSF}$ induced a dose-dependent increase in the number of

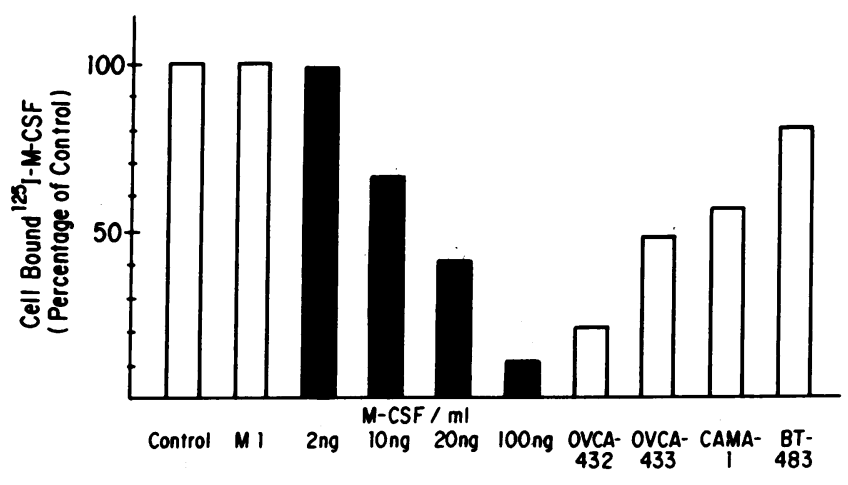

Figure 1. Inhibition of radioiodinated M-CSF binding to M1 cells in the presence of culture supernatants. Mouse myeloblast, M1 cells $\left(10^{6}\right)$ were incubated with radioiodinated M-CSF in the presence or absence of culture supernatants obtained from tumor cell lines. A known amount of recombinant M-CSF was added to another set of wells and incubated in parallel at $4^{\circ} \mathrm{C}$ overnight. The culture supernatants were concentrated to either 30-fold (M1, CMAM-1, BT-483) or 50-fold (OVCA-432, OVCA-433) by ultrafiltration before analysis. Normal tissue culture media concentrated to similar extent were used as control. 
Table III. Effect of Culture Supernatants on Mouse Bone Marrow Cells

\begin{tabular}{lc}
\hline \multicolumn{1}{c}{ Cell line } & ${ }^{*}$ CFU-M/10 $0^{6}$ bone marrow cells \\
\hline Control & $2, \quad 1(1.5)$ \\
M-CSF, $2.5 \mathrm{ng} / \mathrm{ml}$ & $21,26(23.5)$ \\
M-CSF, $10.0 \mathrm{ng} / \mathrm{ml}$ & $77,79(78)$ \\
OVCA-432 & $224,248(236)$ \\
OVCA-420 & $432,416(424)$ \\
BT-20 & $2,2(2)$ \\
M1 & $1,1(1)$ \\
\end{tabular}

* Colonies containing more than 30 cells were counted. Values in parentheses indicate the mean of duplicate cultures. The culture supernatants from the ovarian tumor cell lines OVCA-432 and OVCA- -420 contained 3.8 and $6.5 \mathrm{ng} / \mathrm{ml}$ of M-CSF as determined by radioimmunoassay.

CFU-M colonies. Inclusion of OVCA-420 and OVCA-432 culture supernatants dramatically increased the number of macrophage colonies, indicating thereby that the ovarian cancer cells produce functionally active M-CSF molecules. The pronounced effect of the OVCA-432 and 420 supernatants on macrophage colony formation well above that expected based on the level of M-CSF could indicate the production of other factors also from these cells. In contrast, addition of culture supernatants from M1 cells and BT-20 cells, which are negative for the production of M-CSF, did not induce the growth of macrophage colonies.

Analysis of M-CSF $m R N A$ in ovarian tumor cells. To confirm the production of M-CSF by ovarian tumor cell lines, total cellular RNA was analyzed for the presence of M-CSF transcripts by Northern blot. HL-60 cells stimulated with phorbol myristate acetate (PMA) served as a positive control. The Northern blot analysis revealed significant amounts of M-CSF message in cellular RNA isolated from the ovarian cell lines (Fig. 2). Two of the cell lines analyzed (OVCA-420 and OVCA-429) showed higher levels of M-CSF message, while

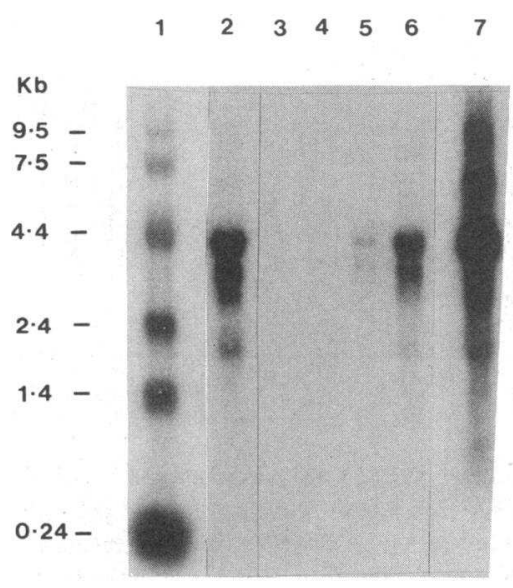

Figure 2. Northern blot analysis of total RNA from ovarian cancer cells. Total cellular RNA isolated from OVCA-429 (lane 2), M1 (lane 3), OVCAR-3 (lane 4), OVCA-433 (lane 5), OVCA-420 (lane 6) and HL-60 (lane 7) was analyzed for the presence of M-CSF related transcripts. Numbers represent the size (in $\mathrm{kb}$ ) of RNA standards run in parallel (lane 1). All the

samples and the RNA standards were run together in the same gel and transferred to nitrocellulose. After hybridization, the lane containing RNA ladder was cut and hybridized separately with nick translated labmda DNA. The remaining portion of the membrane was hybridized with labeled M-CSF probe. Lanes 2-7 represent data from the same blot/autoradiogram.
RNA isolated from OVCA-433 cells had relatively lower amounts of transcripts. Both Ovcar-3 and M1 cells had no detectable M-CSF message under the conditions described. The level of M-CSF transcripts correlated well with the amount of growth factor secreted by these cell lines as measured by the radioimmunoassay. All the positive cell lines contained a major transcript of $4.2 \mathrm{~kb}$ and smaller transcripts of $3.4,2.9$, and $1.9 \mathrm{~kb}$.

\section{Discussion}

Tumor cells produce various endocrine or growth factors that appear to be unrelated to the tissue of origin of the tumor. Some of these factors stimulate the cells from which they are derived (autocrine; 32-35) while others influence distinct population of cells (paracrine; 13-16). Previous work on the growth of ovarian cancer cells in vitro has indicated a positive interaction between macrophages and tumor cells. Understanding the mechanisms of interrelationship between monocytes and tumor cells could be important in developing therapeutic strategies.

In the present study, investigations were carried out to determine whether human tumor cell lines produce M-CSF. Among the various cell lines checked, the production of an M-CSF-like factor was prevalent in epithelial tumors and not with lymphoid malignancies. Most of the leukemia cell lines were negative with the exception of KG-1 and KG-1a cells (acute myelogenous leukemia cells; AML) which secreted low level of M-CSF activity into the culture medium. This observation is consistent with a recent report showing the expression of M-CSF in fresh human AML cells (36). Almost all the ovarian carcinoma cells secreted significant amounts of M-CSF activity. Four lines of evidence support the conclusion that the M-CSF activity is comparable to the authentic M-CSF: (a) The growth factor was immunologically related to recombinant M-CSF, $(b)$ it competed with radioiodinated recombinant M-CSF for binding to a murine myeloid leukemia cell line, $(c)$ mouse bone marrow cultures were dramatically stimulated by the culture supernatants from ovarian cancer cells resulting in the production of macrophage colonies, and (d) Northern blot analysis of total cellular RNA showed the expected pattern of multiple transcripts for M-CSF.

Three of the ovarian cancer cell lines secreted relatively higher levels of M-CSF. Changes in transcription of the M-CSF gene may be responsible for the higher production in these cell lines. This notion is supported by Northern blot analysis, which demonstrated the presence of M-CSF transcripts in greater abundance in those cells secreting higher levels of the growth factor into the medium. This could have resulted from gene amplification, by changes in the promoter/ enhancer elements associated with the gene or by increased levels or activity of transactivating factors.

Northern blot analysis showed four different RNA species of varying length, with a major form of $4.2 \mathrm{~kb}$. All the different forms of the transcripts were also present in HL-60 cells stimulated with PMA. Various sizes of M-CSF transcripts have also been observed in a human pancreatic carcinoma cell line, MIA Paca-2 (31) and other cell lines of human and mouse origin $(37,38)$. Differential splicing is suggested to be responsible for the production of multiple transcripts. In fact, Ladner et al. (39) have recently identified additional splice acceptor site in 
exon 6 from cDNA sequence analyses. The implications of multiple transcripts are not known. It is interesting to note that ovarian carcinoma cells are constitutively expressing multiple forms of M-CSF transcripts. Uninduced MIA Paca-2 cells, for example, contained only the higher molecular weight M-CSF mRNA (31) and did not produce any detectable amount of M-CSF. Only upon induction with PMA, smaller transcripts appeared with the concomitant synthesis of the growth factor. Studies in mice (40) indicate cell-type specific preferential expression of the different forms of M-CSF message. Mouse fibroblasts predominantly (95\%) expressed $4.6 \mathrm{~kb}$ transcript, while the uterus of pregnant mice showed a major species of $2.3 \mathrm{~kb}$. In the present study, a normal human foreskin fibroblast cell line (Huff), produced the highest amount of M-CSF among the different cell lines tested. It would be interesting to investigate the size of M-CSF transcripts in this cell line. Fibroblast cells and fibrosarcoma cell lines are a good source of M-CSF. Native M-CSF was purified from the conditioned media of these cell lines $(41,42)$.

The regulation of growth factors produced by ovarian carcinoma cells and their relevance to tumor cell proliferation may have implications in the management of the disease. Further studies are necessary to understand the importance of interaction between macrophages and ovarian tumor cells.

\section{Acknowledgments}

We acknowledge the help provided by Henry Bryant.

This work was supported in part by a grant from Genetics Institute, Cambridge, MA and by the Lucille P. Markey Charitable Trust. Stephen Brandt is a Lucille P. Markey Scholar.

\section{References}

1. Doolittle, R. F., M. W. Hunkapillar, L. E. Hood, S. G. Devare, E. C. Robbins, S. A. Aaronson, and H. N. Antoniaiades. 1983. Simian sarcoma virus onc gene, v-sis, is derived from the gene (or genes) encoding a platelet-derived growth factor. Science (Wash. DC). 221:275-277.

2. Waterfield, M. D., G. T. Scarce, N. Whittle, P. Stroobant, A. Johnsson, A. Wasteson, B. Westermark, C. H. Heldin, J. S. Huang, and T. F. Deuel. 1983. Platelet-derived growth factor is structurally related to the putative transforming protein $\mathrm{p} 28^{\mathrm{sis}}$ of simian sarcoma virus. Nature (Lond.). 304:35-39.

3. Downward, J., Y. Yarden, E. Mayes, G. Scarce, N. Totty, P. Stockwell, A. Ullrich, J. Schlessinger, and M. D. Waterfield. 1984. Close similarity of epidermal growth factor receptor and v-erb-B oncogene protein sequences. Nature (Lond.). 307:521-527.

4. Ullrich, A., L. Coussens, J. S. Hayflick, T. J. Dull, A. Gray, A. W. Tam, J. Lee, Y. Yarden, T. A. Livermann, J. Schlessinger, J. Downward, E. L. V. Mayes, N. Whittle, M. D. Waterfield, and P. H. Seburg. 1984. Human epidermal growth factor receptor $\mathrm{cDNA}$ sequence and aberrant expression of the amplified gene in A431 epidermoid carcinoma cells. Nature (Lond.). 309:418-425.

5. Scherr, C. J., C. W. Rettenmier, R. Sacca, M. F. Roussel, A. T. Look, and E. R. Stanley. 1981. The c-fms proto-oncogene product is related to the receptor for the mononuclear phagocyte growth factor, CSF-1. Cell. 41:665-676.

6. Yunis, J. J. 1983. The chromosomal basis of human neoplasia. Science (Wash. DC). 221:227-235.

7. Neuberger, M. S., and F. Calabi. 1983. Reciprocal chromosome translocation between c-myc and immunoglobulin gamma $2 \mathrm{~b}$ genes. Nature (Lond.). 305:240-243.
8. King, C. R., M. H. Kraus, and S. A. Aaronson. 1985. Amplification of a novel v-erb-B-related gene in a human mammary carcinoma. Science (Wash. DC). 229:974-976.

9. Varmus, H. E. 1984. The molecular genetics of cellular oncogenes. Annu. Rev. Genet. 18:553-612.

10. Yokota, J., K. Toyoshima, T. Sugimura, T. Yamamoto, M. Terada, H. Battifora, and M. J. Cline. 1986. Amplification of c-erb-B-2 oncogene in human adenocarcinomas in vivo. Lancet. i:765-766.

11. Lee, M. Y., and J. L. Lottsfeldt. 1984. Augmentation of neutrophilic granulocytic progenitors in the bone marrow of mice with tumor-induced neutrophilia: cytochemical study of in vitro colonies. Blood. 64:499-506.

12. Asano, S., A. Urabe, T. Okabe, N. Sata, Y. Kando, Y. Ueyama, S. Chiba, N. Ohsawa, and K. Kosaka. 1977. Demonstration of granulopoietic factor(s) in the plasma of nude mice transplanted with a human lung cancer and in the tumor tissue. Blood. 49:845-852.

13. Obara, T., Y. Ito, T. Kodama, Y. Fujimoto, H. Mizoguchi, K. Oshimi, M. Takahashi, and A. Hirayama. 1985. A case of gastric carcinoma associated with excessive granulocytosis. Production of a colony-stimulating factor by the tumor. Cancer (Phila.). 56:782-788.

14. Suda, T., Y. Miura, H. Mizoguchi, K. Kubota, and F. Takaku. 1980. A case of lung cancer associated with granulocytosis and production of colony-stimulating activity by the tumor. Br. J. Cancer 41:980-984, 1980.

15. Takeda, A., K. Suzumori, Y. Sugimoto, Y. Yagami, T. Miyazawa, C. Yamada, and M. Matsuyama. 1984. Clear cell carcinoma of the ovary with colony stimulating factor production. Cancer (Phila.). 54:1019-1023.

16. Ikeda, K., K. Motoyoshi, Y. Ishizaka, K. Hatake, S. Kajigaya, M. Saito, and Y. Miura. 1985. Human colony-stimulating activityproducing tumor: Production of very low mouse-active colony-stimulating activity and induction of marked granulocytosis in mice. Cancer Res. 45:4144-4149.

17. Buick, R. N., S. E. Fry, and S. E. Salmon. 1980. Effect of host-cell interactions on clonogenic carcinoma cells in human malignant effusions. J. Cancer. 41:695-704.

18. Welander, C. E., R. B. Natale, and J. L. Lewis, Jr. 1982. In vitro growth stimulation of human ovarian cancer cells by xenogenic peritoneal macrophages. J. Natl. Cancer Inst. 69:1039-1047.

19. Mills, G. B., C. May, M. McGill, C. M. Roifman, and A. Mellors. 1988. A putative growth factor in ascitic fluid from ovarian cancer patients. Identification, characterization and mechanism of action. Cancer Res. 48:1066-1071.

20. Fogh, J., and G. Trempe. 1975. New human tumor cell lines. In Human tumor cells in vitro. J. Fogh, editor. Plenum Press, New York. 115-153.

21. Fogh, J., W. C. Eright, and J. D. Loveless. 1977. Absence of HeLa cell contamination in 169 cell lines derived from human tumors. J. Natl. Cancer Inst. 58:209-214.

22. Lasfargues, E. Y., W. G. Coutinho, and E. S. Redfield. 1978. Isolation of two human tumor epithelial cell lines from solid breast carcinomas. J. Natl. Cancer Inst. 21:1131-1147.

23. Soule, H. D., A. Vazquez, A. Long, S. Albert, and M. A. Brennan. 1973. Human cell line from a pleural effusion derived from a breast carcinoma. J. Natl. Cancer Inst. 51:1409-1413.

24. Lasfargues, E. Y., and L. J. Ozzello. 1958. Cultivation of human breast carcinomas. J. Natl. Cancer Inst. 21:1131-1147.

25. Bast, R. C., Jr., M. Feeney, H. Lazarus, L. M. Nadler, R. B. Colvin, and R. C. Knapp. 1981. Reactivity of a monoclonal antibody with human ovarian carcinoma. J. Clin. Invest. 68:1331-1337.

26. Guilbert, L. J., and E. R. Stanley. 1980. Specific interaction of murine colony-stimulating factor with mononuclear phagocytic cells. J. Cell Biol. 85:153-159.

27. Kubota, K., H. Minzoquichi, Y. Miura, T. Suda, and F. Takaku. 1980. A new technique for the cytochemical examination of human hematopoietic cells grown in agar gel. Exp. Hematol. 8:339344. 
28. Chirgwin, J. M., A. E. Przybyla, R. J. MacDonald, and W. J. Rutter. 1979. Isolation of biologically active ribonucleic acid from sources enriched in ribonuclease. Biochemistry. 18:5294-5299.

29. Horiguchi, J., M. K. Warren, P. Ralph, and D. Kufe. 1986. Expression of the macrophage specific colony-stimulating factor (CSF-1) during human monocyte differentiation. Biochem. Biophys. Res. Commun. 141:924-930.

30. Maniatis, T. E., F. Fritsch, and J. Sambrook. 1982. Molecular cloning. Cold Spring Harbor Laboratory, Cold Spring Harbor, NY.

31. Kawasaki, E. S., M. B. Ladner, A. M. Wang, J. V. Arsdell, M. K. Warren, M. Y. Coyne, V. L. Schweickarf, M.-T. Lee, K. J. Wilson, A. Boosman, E. R. Stanley, P. Ralph, and D. F. Mark. 1985. Molecular cloning of a complementary DNA encoding human macrophage specific colony-stimulating factor (CSF-1). Science (Wash. DC). 230:291-296.

32. Marguardt, H., and G. J. Todaro. 1982. Human transforming growth factor: production of melanoma cell line, purification and initial characterization. J. Biol. Chem. 257:5220-5225.

33. Huang, J. S., S. S. Huang, and T. F. Deuel. 1984. Transforming protein of Simian Sarcoma virus stimulates autocrine cell growth of SSV-transformed cells through PDGF cell-surface receptors. Cell. 39:79-87.

34. Cuttitta, F., D. N. Carney, J. Mulshine, T. W. Moody, J. Fedorrko, A. Fischler, and J. D. Minna. 1985. Bombesin-like peptides can function as autocrine growth factors in human small cell lung cancer. Nature (Lond.). 316:823-826.

35. Anzano, M. A., A. B. Roberts, J. E. DeLarco, L. M. Wakefield, R. K. Assian, N. S. Rooke, J. M. Smith, J. E. Lazarus, and M. B. Sporn.
1985. Increased secretion of type B-transforming growth factor accompanies viral transformation of cells. Mol. Cell. Biol. 5:242-247.

36. Rambaldi, A., N. Wakamiya, E. Vellenga, J. Horinguchi, M. Kim Warren, D. Kufe, and J. D. Griffin. 1988. Expression of the macrophage colony-stimulating factor and c-fms genes in human acute myeloblastic leukemia cells. J. Clin. Invest. 81:1030-1035.

37. Wong, G. G., P. A. Temple, A. C. Leary, et al. 1987. Human CSF-1: Molecular cloning and expression of 4-Kb cDNA encoding the human urinary protein. Science (Wash. DC). 235:1504-1508.

38. Rajavashisth, T. B., R. Eng, R. K. Shadduck, A. Waheed, C. M. Ben-Avram, J. E. Shirely, and A. J. Lusis. 1987. Cloning and tissuespecific expression of mouse macrophage colony-stimulating factor mRNA. Proc. Natl. Acad. Sci. USA. 84:1157-1161.

39. Ladner, M. B., G. A. Martin, J. A. Noble, D. M. Nikoloff, R. Tal, E. S. Kawasaki, and T. J. White. 1987. Human CSF-1: gene structure and alternative splicing of mRNÄ precursors. Eur. Mol. Biol. Organ. J. 6:2693-2698.

40. Pollard, J. W., A. Bartocci, R. Arceci, A. Orlofsky, M. B. Ladner, and E. R. Stanley. 1987. Apparent role of macrophage growth factor, CSF-1, in placental development. Nature (Lond.). 330:484486 .

41. Stanley, E. R., and P. M. Heard. 1977. Factors regulating macrophage production and growth. Purification and some properties of the colony-stimulating factor from medium conditioned by mouse $\mathrm{L}$ cells. J. Biol. Chem. 252:4305-4312.

42. Sakai, N., M. Kubota, M. Shikita, M. Yokota, and K. Ando. 1987. Intraclonal diversity of fibrosarcoma cells for the production of macrophage colony-stimulating factor and granulocyte colony-stimulating factor. J. Cell. Physiol. 133:400-404. 